\title{
The Role Of Youth In The Implementation Of Kotaku Program In Langsa City
}

\author{
${ }^{1}$ Raja Syahputra, ${ }^{2}$ Suwardi Lubis, ${ }^{3}$ Sakhyan Asmara \\ ${ }^{1}$ Regional and Rural Development Planning Study Program \\ ${ }^{123}$ Universitas Sumatera Utara, Medan \\ ${ }^{*}$ Corresponding author: \\ Email: syahraja00@gmail.com
}

\begin{abstract}
This study aims to determine the role of youth in the implementation of the KOTAKU program in Langsa City, to determine the factors that encourage and hinder youth in implementing the KOTAKU program in Langsa City. The analytical method used in this research is a qualitative descriptive analysis method by looking at the role of youth and inhibiting and supporting factors in the activities of the KOTAKU program in Langsa City. This research was conducted in Langsa City by using a sample in several areas in Langsa City that have implemented KOTAKU program activities. The results of research on youth in Langsa City play an active role in the KOTAKU program activities in Langsa City. The driving factor for the KOTAKU program activities is the participation of youth and communities who want their living areas to be free from slum settlements. Meanwhile, the inhibiting factor is the lack of public understanding of the KOTAKU program and the lack of public awareness in maintaining the infrastructure, facilities and infrastructure resulting from the KOTAKU program activities in Langsa City.
\end{abstract}

Keywords: Role, Youth, KOTAKU Program

\section{INTRODUCTION}

Population growth and development can lead to access to the emergence of slums and slums, the emergence of slums is often seen as something that has the potential to cause problems in urban areas. One of the city areas that have implemented the KOTAKU program is Langsa City. Kotaku program has been implemented in Langsa City since 2016, spread across five (5) sub-districts consisting of 66 villages / gampong. The handling of slums in Langsa Municipality in general has not worked as it should. This can be seen from the many slum conditions scattered in several villages in the jurisdiction of Langsa City. The total area of the slum reached 87,670 ha based on The Mayor's Decree No.324/413/2016, spread across five gampong, namely Lhok Bani, Kuala Langsa, Telaga Tujuh, Sungai Pauh, and Baroh Langsa Lama.

The five villages that have obtained the mayor's decree are designated as villages with slum handling. While other villages fall into the category of prevention. In implementing the city without slums program in Langsa City from the five designated areas, The Village of Pauh River is an area that has started to run a city program without slums (preliminary observation of research) [1]. In an effort to support the National program, namely the handling of slums covering an area of 87,670 ha and the prevention of slums in Langsa City, Aceh Province, kotaku program through the skilled hands of city facilitators and village level is currently in the stage of mentoring the preparation of settlement profiles based on baseline data 100-0-100. The profile that has been compiled will later become a basic reference in the preparation of the Planning Document of the Settlement Environmental Planning Plan (RPLP) and the Document of The Environmental Planning Of Settlements (RTPLP) [1].In terms of carrying out the activities of the city program without slums in Langsa City in addition to involving the government also involves the local community, especially the youth. To carry out these activities the establishment of groups such as the Group of Benefits and Maintainers (KPP) is an effort to ensure the sustainability of infrastructure built so that it can always be 
utilized and able to maintain the quality of the neighborhood of settlements to be not slums again. With danya the role of youth is expected all areas in langsa city free slums.

The existence of The Group of Benefits and Maintainers (KPP) can provide understanding to the community of the importance of operational and maintenance implementing organizations (O\&P), infrastructure that has been built and the need for the role of the community in these activities, to keep the infrastructure that has been built can still function and useful according to the plan [2] [3].

Based on Law No. 40 of 2009 article 16, Youth plays an active role as a moral force, social control, and agent of change in all aspects of national development. In the framework of the implementation of the active role of youth as referred to in Article 16 and Article 17, the Government, local governments, legal entities, community organizations, and businesses provide opportunities, facilities, and guidance in accordance with the provisions of the legislation.

The Kota Tanpa Kumuh (KOTAKU) program is one of a number of strategic efforts of the Directorate General of Copyright works of the Ministry of Public Works and Public Housing to accelerate the handling of slums in Indonesia and support the "100-0-100 Movement", namely 100 percent universal access to drinking water, 0 percent of slums, and 100 percent access to proper sanitation. The direction of development policy of Dirjen Cipta Karya is to build systems, facilitate local government, and facilitate communities (community-based). Kotaku program will handle slums by building a collaboration platform through increasing the role of local government and community participation. Kotaku program is implemented in 34 provinces, spread across 269 districts / cities, in 11,067 villages / villages. Based on the Decree (SK) of Slums determined by the regional heads of each district / city, the slums located in the target location of the KOTAKU Program is an area of 23,656 Hectares [6].

As an implementation of accelerating the handling of slums, kotaku program will improve the quality, management and prevention of the emergence of new slums, with activities in village / village entities, as well as regions and districts / cities. These slum handling activities include infrastructure development as well as social and economic assistance for the sustainability of better community livelihoods in slum sites [6]. The implementation stage of KOTAKU Program is data collection. Community institutions in villages / villages named Agency / Community Empowerment Institute (BKM/MFI) have conducted baseline data collection of 7 Slum Indicators in their respective villages/villages. The data is integrated between community planning documents and district/city planning documents to determine priority activities to reduce slums and prevent the emergence of new slums. Which will be implemented, either by the community or by other parties, who have expertise in infrastructure development in regional and municipal entities [1].

\section{RESEARCH METHODS}

The data analysis used in this study is qualitative analysis. Data analysis in qualitative methods is done simultaneously through the data collection process. According to Miles and Humberman (1984) data analysis includes data reduction, data presentation, and decision making or verification [4] [5] [7] [8].

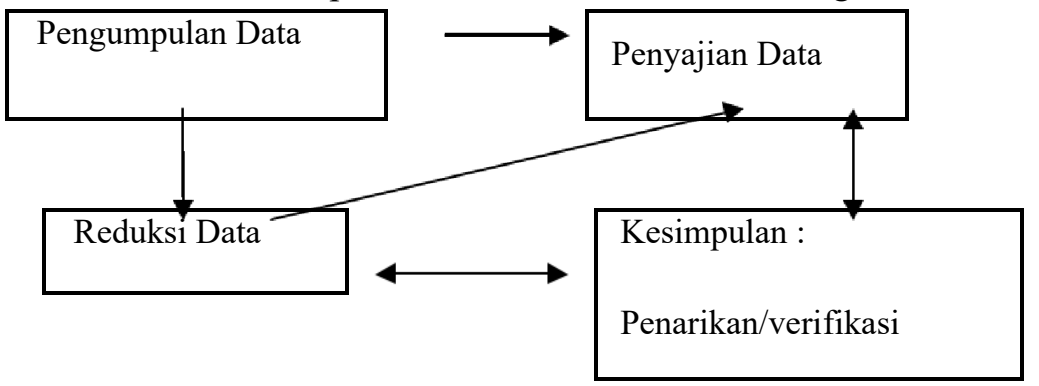

Fig 3.1. Komponen dalam analisis data (interactive model) 


\section{RESULTS OF RESEARCH AND DISCUSSION}

\section{KOTAKU Program In Langsa City}

Langsa City is one of the areas that also runs KOTAKU Program activities. Aceh Province has 6 (six) areas that carry out KOTAKU Program activities, namely Pidie, Aceh Tamiang, Banda Aceh, Langsa, Lhoukseumawe and Subussalam. Kotaku program implemented in Langsa City is an area that looks rundown and has an impact on the surrounding community. The scope of kotaku program activities in Langsa City based on the categories of activities are as follows:

1. Activities to improve the quality of settlements are carried out in all identified slums proposed by the district / city. Especially for urban level infrastructure improvement (primary and secondary infrastructure), investment support from the central government will only be provided to selected cities/districts, which meet certain criteria.

2. Slum prevention activities are carried out in all villages and or urban areas / subdistricts outside the village / village areas identified slums including the location of potential slum-prone settlements identified by the district / city government.

3. Sustainable livelihood development activities are carried out in all quality improvement sites as well as slum prevention.

According to the results of the study, not all areas in Langsa City run kotaku program. Kotaku program implemented in Langsa City is in an area where there are slums and also productive areas that have economic activities. There are some areas in Langsa City that are targeted by kotaku program, it is based on settlements or densely populated areas of the city. Kotaku program is also implemented in productive areas where the ilayah is able to improve the economy of the community. Kotaku program is implemented through non-governmental groups (KSM) consisting of youths in an area that runs the KOTAKU program.

\section{Supporting Factors and Inhibitory Factors of KOTAKU Program in Langsa City}

Supporting Factors and Inhibition of Youth in Developing KOTAKU Program in Langsa City are as follows:

\section{a. Supporting factors}

1. Youth have a high spirit to be involved in kotaku program activities. The high spirit can bring about the willingness to learn to every young man in Langsa City to be involved in kotaku program activities. In addition to obtaining credit they will also gain experience in work.

2. Increase Employment Opportunities so as to overcome unemployment in langsa city. In there are villages that have graduates who are still unemployed so that they have human resources that can be used as escorts in the village.

3. Community Factor. In the development of kotaku program will not succeed if there is no role of society. The community is very happy with the KOTAKU program. Because every activity carried out has many benefits for the community. The community also plays an active role in maintaining and implementing kotaku program.

\section{b. Inhibitory Factors}

i. The role of youth has not been maximized. Limitations of knowledge and skills that young people have. Knowledge and skills of youth are needed to be able to develop kotaku program, but the youth in Langsa City have limited knowledge and skills and thoughts that have not been extensive so as to make the youth less confident and have a high attitude of shame. The skills of youth are still minimal making the local government need tenga experts or youth in other regions. The youths in the village said they only worked as laborers or freelancers.

ii. Lack of community participation in the implementation of KOTAKU program. In fact, community participation in supporting the running of the KOTAKU program is needed at least voluntarily to contribute its energy in the implementation activities of the KOTAKU program. In addition, the community also often forgets in the maintenance of development projects, one of which has been 
implemented. Therefore, there needs to be special activities to fry the citizens in order to maintain the results of development so that the benefits can continue to be enjoyed in the long term.

iii. Lack of understanding of the community akat benefit from a good implementation of kotaku program and lack of community response to problems that occur in the environment itself. Therefore, the need for awareness of each community will have benefits in the implementation of kotaku program for the benefit of the environment itself and the need also to gather information related to the KOTAKU program the need for direct socialization to the cloud community in order to better understand the implementation of the KOTAKU program. In general decision making each program on resource utilization and budget allocation is usually always set by the central government, which in many ways better reflects the needs of small groups of elites who are in power and less reflect the wants and needs of the public. Therefore, the role of youth in development needs to be grown through the opening of a forum that allows the community to participate directly in the decision-making process about development programs in Langsa City. The role of youth in the implementation of KOTAKU rogram is an important element that is often forgotten. Because, the purpose of development is to improve the quality of life of many people so that the equalization of development results is the main goal. In addition, the utilization of development results will stimulate the willingness and volunteerism of the community to always participate in any future program development.

\section{CONCLUSION}

The conclusions in this study are:

1. Youth play an active role in group discussions. The youth in Langsa City got the opportunity to voice their opinions about kotaku program.

2. At the time of kotaku program activities implemented youth in the region are also directly involved either used as labor or as a companion force in the village.

3. The youth in Langsa City also play a role in making decisions about the KOTAKU program.

4. Youth also play an active role in the development of slum areas.

5. Youth are also responsible for maintaining infrastructure and systems that have been built assisted by a team of facilitators.

6. Youth are also involved in implementing supervision of the development process in residential areas.

7. Lack of public awareness in maintaining and caring for kotaku program activities that have been implemented.

8. In the kotaku youth program serves as Agent Development, namely youth is an agent of development of the Indonesian nation in all areas of life, both physical and non-physical

\section{REFERENCES}

[1] Alfiyan, Afifuddin, dan Hayat 2019, Peranan Program Kota Tanpa Kumuh (KOTAKU) dalam Meningkatkan Pembangunan Desa (Studi di Desa Balongmojo Kecamatan Puri Kabupaten Mojokerto).

[2] Akbar dan Igaasi 2019, Peran dan Partisipasi Pemuda Dalam Pengembangan Desa Wisata di desa Pongkar Kabupaten Karimun.

[3] Banurea 2017, Peran Pemuda dalam Pengembangan Daerah Pada Bidang Sosial Budaya dan Ekonomi di Kabupaten Dairi.

[4] Bogdan, Robert, dan Taylor. 1992. Pengantar Metode Penelitian Kualitatif : Suatu Pendekatan Fenomenologis Terhadap Ilmu-ilmu Sosial. Ahli Bahasa Alif Furchan Usaha Nasional. Surabaya.

[5] Burngin. 2011. Penelitian Kualitatif: Komunikasi, Ekonomi, Kebijakan Publik, dan Ilmu Sosial Lainnya. Jakarta: Kencana.

[6] Direktorat Jendreal Cipta Karya Kementrian Pekerjaan Umum dan Perumahan Rakyat. 2019. Program Kota Tanpa Китиһ.

[7] Miles, Mathew.B dan Humberman, A Michael. 1984. Qualitative Data Analysis A Sourcebook Of New Methods. London Sage Publications. 
[8] Moleong, J Lexi. 2001. Metode Penelitian Kualitatif. Bandung: Remaja Rosdakarya.

[9] Undang-Undang No. 40 tahun 2009 pasal 16 dan pasal 17 tentang Kepemudaan.

[10] UU Nomor 1 Tahun 2011 tentang Perumahan dan Kawasan Permukiman Perkembangan Program KOTAKU. 